\title{
Observations on human amniotic fluid cell strains in serial culture
}

\author{
GRANT R. SUTHERLAND, RHONA BAULD, and A. DOUGLAS BAIN \\ Department of Pathology, Royal Hospital for Sick Children and University of Edinburgh, Edinburgh EH9 1 LF
}

\begin{abstract}
Summary. Observations made on 31 amniotic fluid cell strains serially cultured until senescent are recorded. The cell strains had an average life in culture of 13.9 passages (range 3-29). The source of the amniotic fluid from which the cultures were initiated did not influence the behaviour of the cell strains. The behaviour of the cell strains was unrelated to the growth characteristics of the primary cultures from which they were derived. Cell strains derived from serial samples of amniotic fluid from three women were compared and their characteristics were no more related to each other than to the group as a whole. The cell types found in amniotic fluid cultures are described. The karyology of 12 of the cell strains was monitored and no significant changes from normal diploidy were seen. Possible reasons for the highly variable and unpredictable behaviour of amniotic fluid cell strains are discussed.
\end{abstract}

Cultured amniotic fluid cells are now in widespread use for the antenatal diagnosis of chromosome disorders and inborn errors of metabolism (Emery, 1970; Sutherland, 1972; Emery, 1973; Milunsky, 1973). An accurate knowledge of the behaviour of normal cultured amniotic fluid cell strains is therefore essential for their use in genetic studies. However, little appears to be known about the characteristics of these cells in tissue culture. It has been stated (Melancon, Lee, and Nadler, 1971) that there are at least two morphologically distinguishable cell types in amniotic fluid cell cultures-an epithelial type which cannot be subcultured more than two to five times and a fibroblast-like cell which can be cultured for more than 30 passages. On the other hand, Littlefield (1971) has said that ' ...6 to 8 weeks of rapid culture can approach the limit of the growth potential of amniotic fluid cells.... This report records observations made during the long-term culture of 31 amniotic fluid cell strains.

\section{Materials and Methods}

Amniotic fluids were obtained from hysterotomy specimens (HS), by amniocentesis on Rhesus isoimmunized women (RhS) and by artificial rupture of

Received 5 November 1973. membranes (ARM) for the induction of labour. The primary cultures were set up as previously described (Sutherland and Bain, 1972) and subcultured according to the method of Butterworth et al (1973). The cell strains were maintained in $250-\mathrm{ml}$ glass vessels with a growth surface area of $40 \mathrm{~cm}^{2}$ and regularly subcultured on reaching confluency, using a 1:2 subculture ratio. Throughout this study, all cell strains were cultured in Ham's F10 tissue culture medium supplemented with $30 \%$ fetal calf serum and with the antibiotics kanamycin, or penicillin and streptomycin in combination. The methods used for cytogenetic studies on primary cultures have been described (Sutherland, Grace, and Bain, 1973b). Once cell strains became established, chromosome preparations were made using standard methods. Cell strains were stored in $10 \%$ dimethyl sulphoxide in culture medium in the vapour phase of a liquid nitrogen unit.

\section{Results}

The 31 cell strains were derived from amniotic fluid samples taken from 25 women, ie, one woman contributed four samples, another three, and another two at different stages of pregnancy. The gestational ages, means of collection, and chromosomal sexes of the amniotic fluids are shown in Table $I$. All had normal karyotypes with the exception of two samples from one pregnancy which had a karyotype $46, \mathrm{XY}, \mathrm{t}(1 ; 12)(\mathrm{p} 21 ; \mathrm{q} 21)$. 
TABLE I

GESTATIONAL AGES, ORIGINS AND CHROMOSOMAL SEX OF THE 31 AMNIOTIC FLUIDS WHICH YIELDED CELL STRAINS

\begin{tabular}{l|c|c|c}
\hline \multicolumn{1}{c|}{ Origin of Amniotic Fluid } & $\begin{array}{c}\text { Gestation } \\
\text { (weeks) }\end{array}$ & \multicolumn{2}{|c}{ Chromosomal Sex } \\
\cline { 2 - 4 } $\begin{array}{l}\text { Mean }(n=8) \\
\text { Range }\end{array}$ & $\begin{array}{l}16 \cdot 5 \\
11-23\end{array}$ & 2 & 6 \\
\hline ARM $(n=1)$ & 39 & 1 & Female \\
\hline $\begin{array}{l}\text { RhS }(n=22) \\
\text { Mean } \\
\text { Range }\end{array}$ & $\begin{array}{l}28 \cdot 3 \\
18-35\end{array}$ & 9 & 13 \\
\hline $\begin{array}{l}\text { Total }(n=31) \\
\text { Mean } \\
\text { Range }\end{array}$ & $\begin{array}{l}25 \cdot 6 \\
11-39\end{array}$ & 12 & 19 \\
\hline
\end{tabular}

TABLE II

DATA ON 31 AMNIOTIC FLUID CELL STRAINS

\begin{tabular}{|c|c|c|c|c|}
\hline $\begin{array}{c}\text { Origin of } \\
\text { Amniotic Fluid }\end{array}$ & $\begin{array}{c}\text { No. of } \\
\text { Passages }\end{array}$ & $\begin{array}{c}\text { Days in } 1^{\circ} \\
\text { Culture }\end{array}$ & $\begin{array}{l}\text { Days as } \\
\text { Cell } \\
\text { Strain }\end{array}$ & $\begin{array}{c}\text { Mean } \\
\text { Interval } \\
\text { between } \\
\text { Subculture }\end{array}$ \\
\hline $\begin{array}{l}H S(n=8) \\
\text { Mean } \\
\text { Range }\end{array}$ & $\begin{array}{l}12 \cdot 0 \\
4-20 \\
\end{array}$ & $\begin{array}{l}27 \cdot 37 \\
18-29 \\
\end{array}$ & $\begin{array}{l}76 \cdot 63 \\
19-135 \\
\end{array}$ & $\begin{array}{r}6 \cdot 38 \\
4 \cdot 8-9 \cdot 6 \\
\end{array}$ \\
\hline$A R M(n=1)$ & 11 & 27 & 111 & $10 \cdot 1$ \\
\hline $\begin{array}{l}\text { RhS }(n=22) \\
\text { Mean } \\
\text { Range }\end{array}$ & $\begin{array}{l}14 \cdot 77 \\
3-29\end{array}$ & $\begin{array}{l}25 \cdot 91 \\
19-41\end{array}$ & $\begin{array}{l}96 \cdot 63 \\
31-146\end{array}$ & $\begin{array}{c}7 \cdot 36 \\
3 \cdot 0-12 \cdot 0\end{array}$ \\
\hline $\begin{array}{l}\text { Total }(n=31) \\
\text { Mean } \\
\text { Range }\end{array}$ & $\begin{array}{l}13 \cdot 90 \\
3-29\end{array}$ & $\begin{array}{l}26 \cdot 32 \\
18-41\end{array}$ & $\begin{array}{l}91 \cdot 94 \\
19-146\end{array}$ & $\begin{array}{c}7 \cdot 19 \\
3 \cdot 0-12 \cdot 0\end{array}$ \\
\hline
\end{tabular}

Some data on the cell strains are shown in Table II. The differences between the HS and RhS are not significant for any of these parameters. The number of passages is the number of times a cell strain could be subcultured, using a 1:2 subcultivation ratio, before the cell strain died. Death of a cell strain was defined as the point at which it would no longer grow to confluency after subculture. The time as a cell strain was the interval between subculturing the primary culture and the death of the cell strain. The mean interval between subcultures was the time as a cell strain divided by the number of passages till death, and was a crude estimator of the overall rate of growth of a cell strain. The distribution of the number of passages is shown in Table III.

The data were examined to see if any of the parameters of the amniotic fluid were related to the behaviour of the cell strain in culture. There was no correlation between gestational age and the following: time in primary culture, the number of passages
TABLE III

THE DISTRIBUTION OF THE NUMBER OF PASSAGES FOR WHICH THE 31 AMNIOTIC FLUID CELL STRAINS COULD BE CULTURED UNTIL DEATH

\begin{tabular}{l|c|c|c|c|c|c|c}
\hline No. of passages & $0-4$ & $5-8$ & $9-12$ & $13-16$ & $17-20$ & $21-24$ & $>25$ \\
No. of cell strains & 3 & 3 & 8 & 7 & 5 & 3 & 2 \\
\hline
\end{tabular}

to which a cell strain could be cultured or the mean interval between subcultures. Similarly, the number of passages was not correlated with the time in primary culture. There was, however, a significant $(\mathrm{p}<0.01)$ correlation $(r=-0.550)$ between mean subculture interval and the number of passages (Fig. 1).

All cell strains which survived more than five or six passages were stored in the liquid nitrogen unit. Thirteen strains have been retrieved and then cultured to senescence. The mean number of passages before death of the 13 strains was 14.5 (range 5-25) and after storage the mean was 13.4 (range 5-24). Most of the retrieved cell strains died within \pm 3 passages of the corresponding strain which had not been stored. The greatest difference was one strain which survived for 17 passages before storage and for only 12 passages after being stored at the fourth passage.

When more than one amniotic fluid sample was collected at different stages from a single pregnancy it was possible to compare the cell strains derived from these samples. Some data relating to three such groups of cell strains are shown in Table IV.

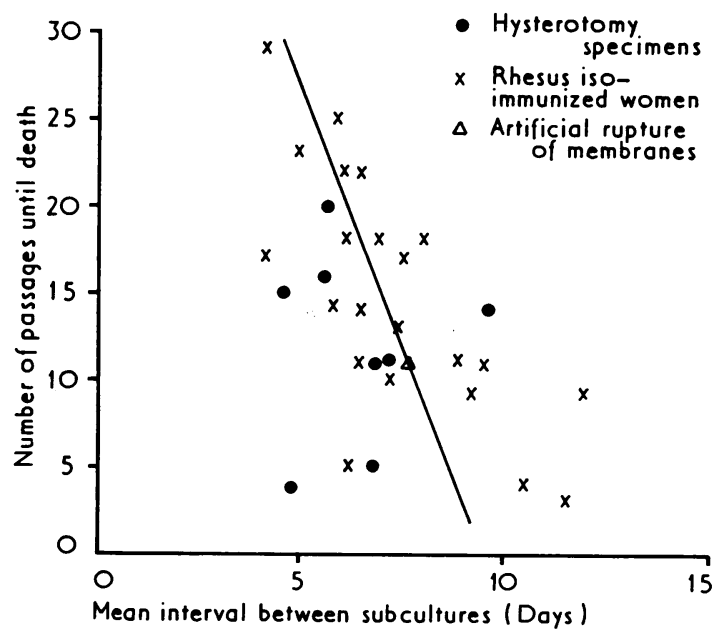

FIG. 1. Relationship between the number of passages for which cell strains could be cultured before death and mean interval between passages. $(r=-0.550$. 
TABLE IV

DATA ON 9 AMNIOTIC FLUID CELL STRAINS COLLECTED FROM THREE PREGNANCIES

\begin{tabular}{|c|c|c|c|c|c|c|}
\hline Group & $\underset{\text { Sex }}{\text { Chromosomal }}$ & $\begin{array}{l}\text { Gestation } \\
\text { (weeks) }\end{array}$ & $\begin{array}{l}\text { Days in } \\
1^{\circ} \text { Culture }\end{array}$ & $\begin{array}{l}\text { No. of } \\
\text { Passages }\end{array}$ & $\begin{array}{l}\text { Days as } \\
\text { Cell Strain }\end{array}$ & $\begin{array}{c}\text { Mean Interval } \\
\text { between } \\
\text { Subcultures }\end{array}$ \\
\hline $1^{*}$ & Male & $\begin{array}{l}22 \\
26\end{array}$ & $\begin{array}{l}28 \\
41\end{array}$ & $\begin{array}{r}11 \\
4\end{array}$ & $\begin{array}{r}106 \\
42\end{array}$ & $\begin{array}{r}9 \cdot 7 \\
10.5\end{array}$ \\
\hline 2 & Female & $\begin{array}{l}18 \\
22 \\
24 \\
35\end{array}$ & $\begin{array}{l}28 \\
24 \\
20 \\
36\end{array}$ & $\begin{array}{r}18 \\
8 \\
15 \\
17\end{array}$ & $\begin{array}{r}144 \\
108 \\
110 \\
69\end{array}$ & $\begin{array}{r}7 \cdot 8 \\
12 \cdot 0 \\
7 \cdot 3 \\
4 \cdot 1\end{array}$ \\
\hline 3 & Female & $\begin{array}{l}23 \\
26 \\
28\end{array}$ & $\begin{array}{l}26 \\
26 \\
19\end{array}$ & $\begin{array}{l}18 \\
22 \\
10\end{array}$ & $\begin{array}{r}125 \\
129 \\
71\end{array}$ & $\begin{array}{l}6 \cdot 9 \\
5 \cdot 9 \\
7 \cdot 1\end{array}$ \\
\hline
\end{tabular}

* This group has a constitutional chromosome abnormality (see text).

The cell strains in each group do not show uniform behaviour, they vary as greatly as cell strains derived from different pregnancies. This may indicate that the genetic make-up of the cells is not responsible for the variable behaviour of the cell strains.

The cell morphology was monitored throughout the period of culture by direct observation under the inverted microscope and by the examination of Giemsa-stained monolayers grown on flying coverslips. There were five readily recognizable cell types.

1. Macrophages (Fig. 2). These were visible the day after primary cultures had been set up. They appear to divide in culture but cannot be subcultured. They degenerate and are overgrown by other cell types. Very few macrophages are seen in amniotic fluid cell cultures except when the amniotic fluid comes from an anencephalic pregnancy, when they are present in considerable numbers (Sutherland, Brock, and Scrimgeour, 1973a).

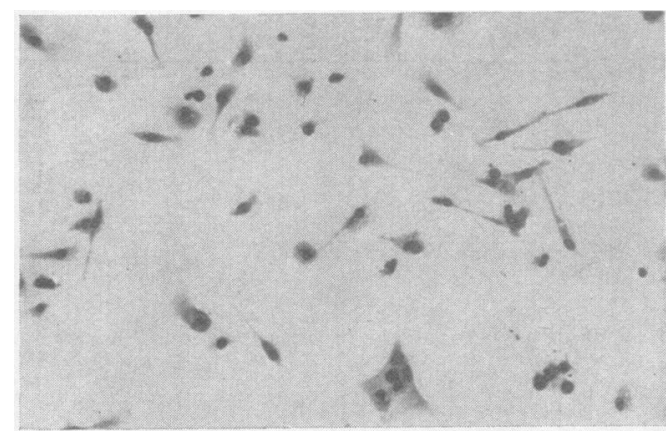

FIG. 2. Macrophages from anencephalic amniotic fluid after 20 hours in culture. (Giemsa stain, $\times 200$.)
2. Epithelioid Type I Cells (Fig. 3) which grow in 'islands' in primary culture. These cells can apparently be subcultured but lose their tendency to grow in 'islands' after subculture.

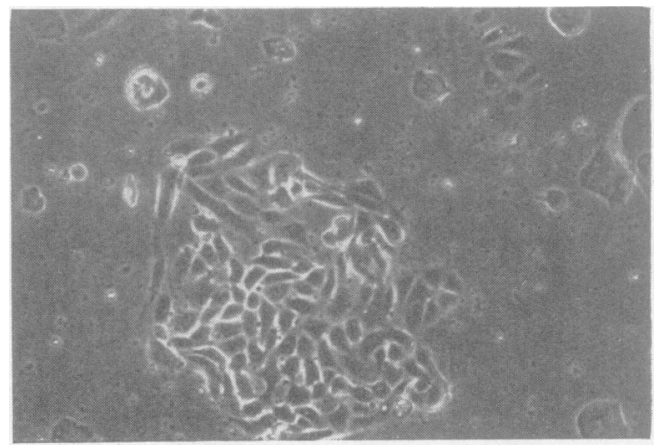

FIG. 3. Epithelioid type I cells after 18 days in primary culture. (Phase contrast, $\times 200$.)

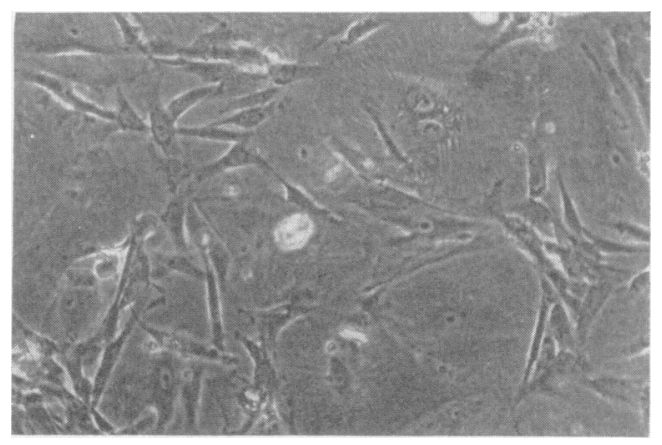

FIG. 4. Epithelioid type II cells after 23 days in primary culture. There are fibroblast-like cells growing between the epithelioid cells. Note one binucleate epithelioid cell and the fibrillar nature of the cytoplasm. (Phase contrast, $\times 200$.) 
3. Epithelioid Type II Cells (Fig. 4). These are very large cells with much cytoplasm and sometimes with more than one nucleus. Under phase contrast the cytoplasm of these cells has a fibrillar appearance. These cells can be subcultured at least 20 times. Almost all primary cultures of amniotic fluid contain these cells.

4. Epithelioid Type III Cells (Fig. 5) which morphologically resemble type I except that they do not grow in islands in primary cultures. In their growth patterns these cells show some of the features of the next cell type. These cells can be readily subcultured.

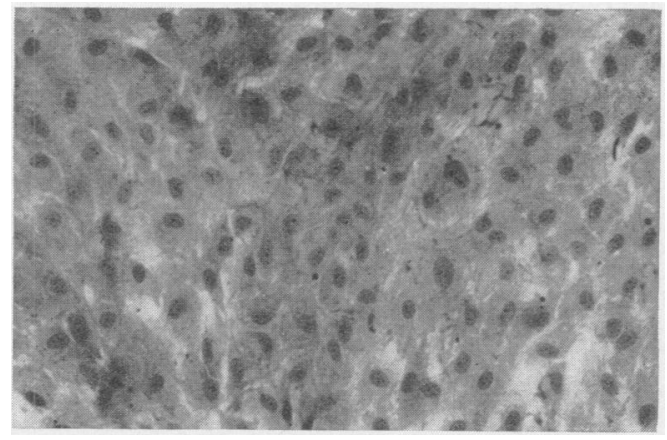

FIG. 5. Epithelioid type III cells in the twenty-second passage of culture. (Giemsa stain, $\times 200$.)

5. Fibroblast-like Cells (Fig. 6) which can be readily subcultured. These are morphologically indistinguishable from fibroblast-like cells cultured from human embryonic lung or skin biopsy.

Most cell strains were a mixture of cell types throughout their life in culture. However, in some cases one type or the other predominated. In this

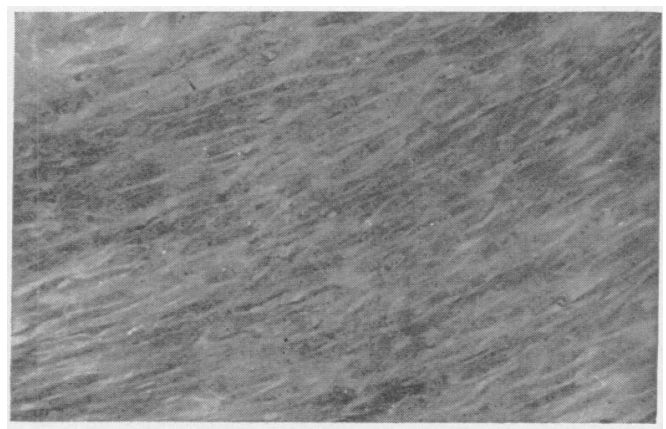

Fig. 6. Fibroblast-like cells in the fourth passage of culture. (Giemsa stain, $\times 200$.) series there was a tendency for the more fibroblastic cultures to live longer; however, some died after less than 10 passages whereas strains in which epithelioid cells predominated lived for more than 20 passages.

The karyology of 12 of the cell strains was monitored to within at least three passages before cell death. At least 10 metaphases per cell strain were examined at this stage and no departure from normal diploid complements was seen," except for that present in two of the cell strains as a constitutional abnormality.

All except five cell strains were tested for mycoplasma contamination on at least one occasion near the end of their life in culture. All cell strains tested were reported free of mycoplasmas.

\section{Discussion}

It is apparent that amniotic fluid cell strains have a highly variable yet finite life-span in culture. In the series reported here senescent strains and actively proliferating strains were in culture at the same time, receiving the same culture medium and being kept under apparently identical conditions. This would suggest that culture factors were not responsible for the variation. The longest surviving cell strain in this series survived 29 subcultures. This, however, is not the upper limit of life of an amniotic fluid cell strain; Melancon et al (1971) have reported that some can be cultured for more than 30 passages, and other cell strains since this series was completed have survived more than 50 passages.

The reasons for the variability in the life of the cell strains remain unclear. In all cases they are derived from fetal tissue and as the survival in culture was not correlated with gestational age, it is unlikely that the variable age of the cells which initiate the primary culture is the reason. Martin, Sprague, and Epstein (1970) have shown that the life span of fibroblast-like cells in tissue culture depends on the tissue used to establish the culture. Skin-derived fibroblasts survived longer than those derived from muscle, testis, or bone marrow spicules. Although the tissue of origin of the cells in amniotic fluid is uncertain they probably come from more than one source (Sutherland and Bain, 1972). Some of the variability seen could possibly be due to different samples of amniotic fluid having different proportions of cells from each possible source, each with a different survival potential in tissue culture.

As there are only a relatively small number of points of outgrowth in the primary culture the number of cell doublings would be much higher than the 
number of passages would imply. This may well be the reason why amniotic fluid cell strains appear to have a shorter life in culture than cell strains grown from other fetal tissues. However, if this was the reason for the variation in the length of life in culture, a correlation between number of passages till death and time in primary culture would be expected: this was not found. The fact that the life in culture is finite is not surprising as Hayflick (1965) has shown that human diploid cells have a limited life span of $50 \pm 10$ passages when grown from fetal tissue.

The finding that the faster growing cell strains live longer is unexpected. This has not been previously reported for human diploid cell strains and the reasons for it remain unknown. Hay (1970) has in fact reported the exact opposite effect for chick embryo fibroblasts.

The variability in life-span of the amniotic fluid cell strains is very like that described by Swim and Parker (1957) for fibroblast-like cell strains. These workers found that the number of times they could subculture cell strains grown from neonatal foreskins ranged from 10 to 34 with a mean of 24 . Cell strains grown from other tissues, including human embryonic lung, survived from two to 32 subcultures. They attributed this variability to inadequate tissue culture medium. Perhaps the same explanation may apply to the amniotic fluid cell strains. Using medium similar to that used in the present series but with only $15 \%$ fetal calf serum supplement, Nadler and Gerbie (1970) were able to subculture only $75 \%$ of 155 successful primary amniotic fluid cell cultures more than three times. Sutherland and Bain (1973) found that $90 \%$ of 62 primary cultures could be subcultured to yield cell strains which could be maintained for at least two subcultures.

The findings in the groups of cell strains grown from serial samples of amniotic fluid are not surprising. As none of the properties studied are related to gestation there is no reason why these cell strains should show either constant features or any trends within the groups. It would be of interest to culture a number of cell strains from a single amniotic fluid sample and to see if they showed the same degree of variation as seen in these groups.

Melancon et al (1971) suggested that cell type may influence length of life in culture. If cell type did affect life in culture then the number of passages till death would be expected to show a multimodal distribution. In this series the distribution of the number of passages is fairly evenly around the mean.

The variety of cell types present in amniotic fluid has received little attention. Gerbie et al (1972) have said that amniotic fluid cell strains are composed of two major cell types, epithelial-like cells and fibroblast-like cells. Melancon et al (1971) have commented that the epithelial-like cells are difficult to subculture and can be maintained for only two to five passages. It is recognized that medium composition can alter cell morphology (eg, Griffiths, 1973). In this regard it should be noted that for this series the medium was prepared in large batches and that the various cell types not only co-existed in the same culture vessel but cell strains of predominantly different morphologies were being cultured concurrently. The only comprehensive report of the various cell types is that of Uhlendorf (1970). He has described fibroblast-like cells and epithelial-like cells corresponding to types II and III of this report. The 'small fusiform cells' which he describes probably correspond to the type I epithelioid cells of this report. When the islands in which these cells grow become large, the cells in the centre of the island become crowded and take on an appearance very similar to that shown in Uhlendorf's Fig. 2. In addition, Uhlendorf described a cell type not recognized in the present series (Fig. 5 in Uhlendorf, 1970).

It is clear that amniotic fluid cell strains are composed of a number of different cell types and that some, if not all, of these can persist as long as the cell strain survives. If the various tissue culture media in general use and the variety of conditions under which these cells can be cultured had the effect of selecting against any particular cell type then this could explain the apparent differences reported in the behaviour of amniotic fluid cell strains. The very act of subculturing may in fact be such a selective mechanism as the fibroblast-like cells are more readily removed from the growth surface than epithelial-like ones. Melancon et al (1971) have indeed used this feature to select cell strains of different morphology.

The findings of normal karyology in the cell strains monitored until senescence is not surprising. The types of chromosome changes which have been described in senescent human diploid fibroblast-like cells (Saksela and Moorhead, 1963) would not have been demonstrated due to the small number of cells examined but any major departure from euploidy would have been detected. No cell lines or cell strains other than those derived from amniotic fluid or urine (Sutherland and Bain, 1972) were handled in the laboratory during the time this work was in progress.

The main question posed by this work is, why cannot all amniotic fluid cell strains be maintained 
for the same length of time as cell strains derived from other fetal tissues? One reason is probably the low cell number used to initiate cultures but this is only part of the answer. The reasons for the variability in life expectancy of these cell strains remain speculative. The factors which prevent these cultures from having a prolonged existence should be identified. The loss of valuable amniotic fluid cell strains at an early passage is a hindrance to building up adequate controls for the antenatal diagnosis of genetic disease using cultured amniotic fluid cells.

We are grateful to Professor A. E. H. Emery for helpful criticisms during the preparation of this report, and to Dr S. Stewart for the Mycoplasma testing. This work was supported in part by the Scottish Advisory Committee on Medical Research and the Secretary of State for Scotland.

\section{REFERENCES}

Butterworth, J., Sutherland, G. R., Broadhead, D. M., and Bain, A. D. (1973). Lysosomal enzymes of cultured amniotic fluid cells. Clinica Chimica Acta, 44, 295-299.

Emery, A. E. H. (1970). Modern Trends in Human Genetics, vol. 1. Butterworth, London.

Emery, A. E. H. (1973). Antenatal Diagnosis of Genetic Disease. Churchill Livingstone, Edinburgh and London.

Gerbie, A. B., Melancon, S. B., Ryan, C., and Nadler, H. L. (1972). Cultivated epithelial-like cells and fibroblasts from amniotic fluid: their relationship to enzymatic and cytologic analysis. American Fournal of Obstetrics and Gynecology, 114, 314-320.

Griffiths, J. B. (1973). The effects of adapting human diploid cells to grow in glutamic acid media on cell morphology, growth and metabolism. Fournal of Cell Science, 12, 617-629.

Hay, R. J. (1970). Cell strain senescence in vitro: cell culture anomaly or an expression of a fundamental inability of normal cells to survive and proliferate. In Aging in Cell and Tissue Culture, ed. by E. Holečková and V. J. Cristofalo, pp. 7-24. Plenum Press, New York.

Hayflick, L. (1965). The limited in vitro lifetime of human diploid cell strains. Experimental Cell Research, 37, 614-636.

Littlefield, J. W. (1971). Problems in the use of cultured amniotic fluid cells for biochemical diagnoses. Birth Defects: Original Article Series, 7, pt. 5, pp. 15-17. National Foundation-March of Dimes, New York.

Martin, G. M., Sprague, C. A., and Epstein, C. J. (1970). Replicative life-span of cultivated human cells. Effects of donor's age, tissue and genotype. Laboratory Investigation, 23, 86-92.

Melancon, S. B., Lee, S. Y., and Nadler, H. L. (1971). Histidase activity in cultivated human amniotic fluid cells. Science, 173, 627-628.

Milunsky, A. (1973). The prenatal diagnosis of hereditary disorders. Charles C. Thomas, Springfield.

Nadler, H. L. and Gerbie, A. B. (1970). Role of amniocentesis in the intrauterine detection of genetic disorders. The New England fournal of Medicine, 282, 596-599.

Saksela, E., Moorhead, P. S. (1963). Aneuploidy in the degenerative phase of serial cultivation of human cell strains. Proceedings of the National Academy of Sciences, U.S.A., 50, 390-395.

Sutherland, G. R. (1972). The role of amniocentesis in genetic counselling. Australian fournal of Mental Retardation, 2, 85-92.

Sutherland, G. R. and Bain, A. D. (1972). Culture of cells from the urine of newborn children. Nature, 239, 231.

Sutherland, G. R. and Bain, A. D. (1973). Antenatal diagnosis of inborn errors of metabolism: Tissue culture aspects. Humangenetik, 20, 251-255.

Sutherland, G. R., Brock, D. J. H., and Scrimgeour, J. B. (1973a). Amniotic-fluid macrophages and anencephaly. Lancet, 2. 10981099.

Sutherland, G. R., Grace, E., and Bain, A. D. (1973b). Metaphase chromosomes from neonatal urine. Humangenetik, 17, 273-275.

Swim, H. E. and Parker, R. F. (1957). Culture characteristics of human fibroblasts propagated serially. American fournal of Hygiene, 66, 235-243.

Uhlendorf, B. W. (1970). Use of amniotic fluid and reliability of diagnostic procedures. In Early Diagnosis of Human Genetic Defects, ed. by M. Harris. Fogarty International Center Proceedings No. 6, pp. 149-168. Government Printing Office, Washington. 